\title{
Improvements to x-ray diffractometers: Heaters, hygrometry, and thermodifferential and spectra analyses
}

\author{
J. Garcia-Guinea ${ }^{\mathrm{a})}$ and R. Ortiz \\ Museo Nacional Ciencias Naturales, CSIC, Jose Gutierrez Abascal 2, Madrid 28006, Spain \\ V. Correcher \\ CIEMAT Avenida Complutense 22, Madrid 28040, Spain
}

\author{
A. La Iglesia \\ Madrid 28040, Spain

\section{J. D. Martín-Ramos} \\ Universidad de Granada, Avenida Fuentenueva s/n, Granada 18002, Spain
}

Instituto de Geologia Económica, CSIC-UCM, Facultad de Ciencias Geologicas, Universidad Complutense,

(Received 6 April 2001; accepted for publication 16 July 2001)

\begin{abstract}
We describe a newly designed stainless steel door which holds cooling fluids and permits the connection of a set of self-improvements to mechanical supplies, sensors, thermocouples, electronic circuits, and new software to traditional x-ray diffraction chambers. Some compatible analytical routines, at various gas temperatures (from 18 to $200^{\circ} \mathrm{C}$ ), stem from restricted combinations of stimulation sources to the sample (x irradiation and heating) and the detector sensors (Geiger $\mathrm{x}$-ray diffraction spectra charge coupled devices, humidity, image TV, thermocouples differential thermal analysis installed). Phase transitions of solids can be detected by spectral, structural, geometrical, and thermodifferential methods. (c) 2001 American Institute of Physics.
\end{abstract}

[DOI: $10.1063 / 1.1403008]$

The concept of appropriate technology is crucial for developing countries, and it serves as an alternative to buying expensive new instruments. Many research centers in these countries use x-ray diffractometers to study structural phases in powdered mixtures (e.g., rocks, materials, etc.). In a previous paper $^{1}$ we suggested a simple, inexpensive modification of the traditional diffractometer which allows the heating of samples at gas temperatures of $20-200{ }^{\circ} \mathrm{C}$ using only a halogen lamp and proportional integral differential (PID) thermal control. The new concept presented here permits modern electronic supplies to be plugged into the $\mathrm{x}$-ray chamber (see Table I). The increased availability of quality components from the microelectronics industry has also created a demand for such systems. ${ }^{2}$ New electric resistance, thermocouples, and halogen lamps can easily be coupled to old x-ray cameras while maintaining management of the $\mathrm{x}$-ray diffractometer. The increased use of charge coupled devices (CCD) in $\mathrm{x}$-ray applications ${ }^{3}$ also suggests the installation of a CCD fiberoptic spectrometer to obtain radioluminescence visible spectra from the $\mathrm{x}$-irradiated sample. The high cost of high-temperature chambers used in x-ray diffraction (XRD) procedures stems from the need to use platinum strips, expensive refractory panels, etc. However, there are many hydrated materials that show detectable processes under $200{ }^{\circ} \mathrm{C}$ such as dehydration, first dehydroxylation, phase transitions, thermal expansion, ionic self-diffusion, etc. It is possible to obtain limited thermal use (up to $200^{\circ} \mathrm{C}$ ) using old XRD chambers by introducing simple heating and

\footnotetext{
${ }^{a)}$ Corresponding author; electronic-mail: guinea@mncn.csic.es
}

TABLE I. Compatible analytical routines in the new thermal XRD-RL-DTA device. (Note: For geometrical reasons, compatible measurements are ABE, $\mathrm{ACE}$, and $\mathrm{ADE}$.)

\begin{tabular}{|c|c|c|c|}
\hline \multirow{2}{*}{$\begin{array}{l}\text { Sample } \\
\text { Analysis } \\
\text { Method }\end{array}$} & \multicolumn{3}{|c|}{ Sample stimulation method } \\
\hline & $\begin{array}{l}\text { X-ray } \\
\text { (RT) }\end{array}$ & $\begin{array}{c}\text { Halogen } \\
\text { heater }\end{array}$ & $\begin{array}{l}\text { Ceramic } \\
\text { heater }\end{array}$ \\
\hline $\begin{array}{l}\text { Geiger } \\
\text { (Bragg } \\
\text { law) } \\
\text { (A) }\end{array}$ & $\begin{array}{l}\text { Diffractogram } \\
\text { (geometrical } \\
\text { parameters, } \\
\text { identification } \\
\text { of samples) }\end{array}$ & $\begin{array}{c}\text { Structural } \\
\text { changes } \\
\text { under } \\
\text { light } \\
\text { irradiation } \\
\text { during heating } \\
\text { ramps }\end{array}$ & $\begin{array}{c}\text { Structural } \\
\text { changes } \\
\text { during heating } \\
\text { ramps } \\
\text { (darkness) }\end{array}$ \\
\hline $\begin{array}{l}\text { Spectra } \\
\text { (B) }\end{array}$ & $\begin{array}{l}\text { Spectra at } \\
\text { room } \\
\text { temperature } \\
\text { (standard } \\
\text { radiolumi- } \\
\text { nescence) }\end{array}$ & $\begin{array}{c}\text { Not } \\
\text { possible }\end{array}$ & $\begin{array}{c}\text { Spectral } \\
\text { changes } \\
\text { during heating } \\
\text { ramps } \\
\text { (darkness) }\end{array}$ \\
\hline $\begin{array}{l}\text { Humidity } \\
\text { (C) }\end{array}$ & $\begin{array}{l}\text { Dehydration } \\
\text { under } \\
\mathrm{x} \text { irradiation } \\
(+ \text { time })\end{array}$ & $\begin{array}{l}\text { Dehydration } \\
\text { under } \\
\text { light } \\
\text { irradiation } \\
\text { during heating } \\
\text { ramps }\end{array}$ & $\begin{array}{c}\text { Dehydration } \\
\text { during heating } \\
\text { ramps } \\
\text { (darkness) }\end{array}$ \\
\hline $\begin{array}{l}\text { TV image } \\
\text { (D) }\end{array}$ & No changes & $\begin{array}{c}\text { Color, } \\
\text { fissures, shape } \\
\text { changes }\end{array}$ & $\begin{array}{c}\text { Color, fissures, } \\
\text { shape } \\
\text { changes }\end{array}$ \\
\hline $\begin{array}{l}\text { Differential } \\
\text { thermal } \\
\text { analyses } \\
(E)\end{array}$ & No changes & $\begin{array}{l}\text { Sample and } \\
\text { holder } \\
\text { differential } \\
\text { temperatures } \\
\text { as sample } \\
\text { heating }\end{array}$ & $\begin{array}{l}\text { Sample and } \\
\text { holder } \\
\text { differential } \\
\text { temperatures } \\
\text { as sample } \\
\text { heating }\end{array}$ \\
\hline
\end{tabular}



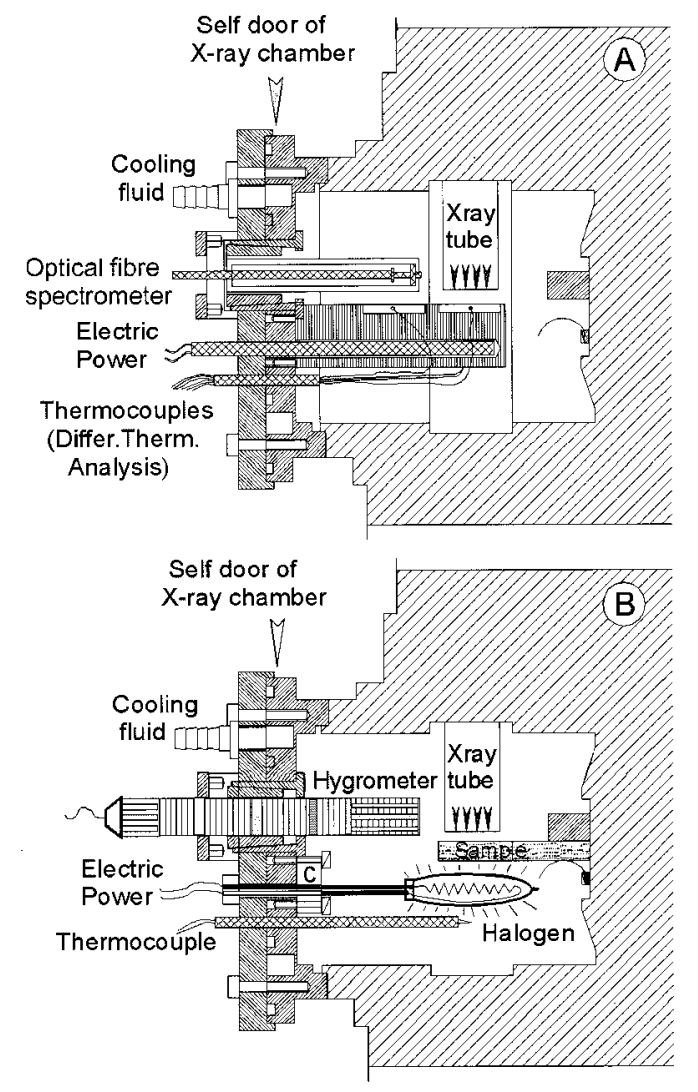

FIG. 1. Traditional $\mathrm{x}$-ray diffraction chamber with two different arrangements for the newly designed stainless steel door: (A) aluminum holder with a thermal ceramic cartridge and DTA and optical fiber of the spectrometer; (B) classic holder with a hygrometer, a halogen lamp, and a thermocouple.

moisturizing systems. In this note we describe simple selfimprovements to upgrade a classic x-ray diffractometer, the Philips PW1710/00, once commonly used in Spain (about 1980). They include a new original water refrigerator, a new stainless steel door to hold internal cooling fluids, internal heaters (resistance and halogen lamp) in new sample holders, under PID thermal control, a holder to hang the optical fiber of the CCD spectrometer, and a new electronic circuit and software to record differential thermal analyses between the sample and the reference.

Using modern electronic supplies, numerous additional tasks can be performed while maintaining usual management of the x-ray diffractometer, thus allowing free movement of the goniometer, but without heating the neighboring equipment (Geiger counter, x-ray tube) and sealing possible leaks of ionized air. The simplest method for achieving this was to modify only the door of the sample chamber. To preserve the diffractometer for its daily task of identifying samples, a new rounded door was constructed (Fig. 1). Using this new door, different sets of constructed and marketable supplies were fitted to the door.

For fitting to the door we considered the following conditions: (1) use of a nonoxidizable material such as stainless steel, (2) sealed channels on the inside of the door to allow cooling fluids to flow and thus prevent uncontrolled heating. This was achieved by coupling two pieces of steel with refractory watertight joints and screws with copper washers, which flow under pressure, sealing the holes (Figs. 1 and 2),

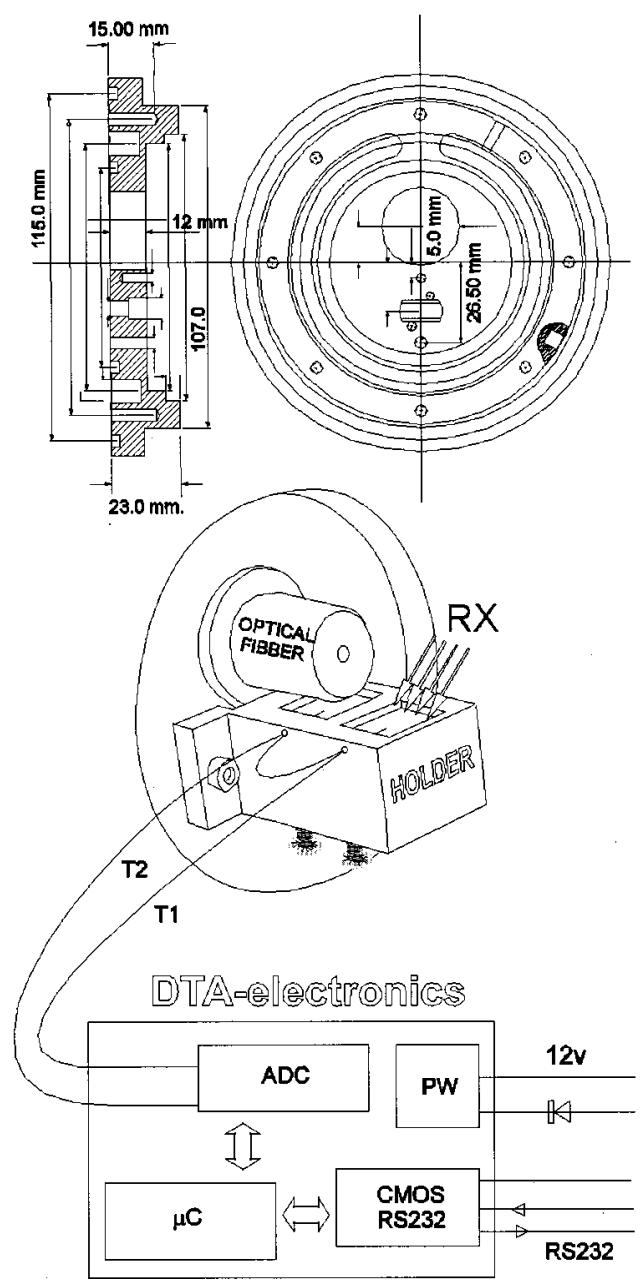

FIG. 2. Details of the new sample holder and the differential thermal analysis system.

(3) a multipurpose subdoor with different couplings to install the micro-TV camera, the environmental hygrometer sensor, the optical fiber, and additional sensor detectors, (4) a gate to the thermocouples [thermal control, differential thermal analyses (DTA)], and (5) a gate to electrical wires to supply power to the halogen lamp or the ceramic cartridge.

The gate planned to supply power allows screws to be inserted into one of the two devices [Figs. 1(a) and 1(b)]: an internal ceramic socket to plug the halogen lamp perpendicular to the door (parallel to the sample). The halogen lamp (75 $\mathrm{W}-220 \mathrm{~V})$ emits in the red-infrared spectrum, reaching temperatures of around $210{ }^{\circ} \mathrm{C}$ at a maximum in the thermocouple, (b) an independent aluminum block, which is the sample holder, with a cylindrical hole to fit the ceramic cartridge heater, three different thermocouples: one to the PID thermal controller, one to measure the temperature of the sample, and one to determine the temperature in the reference sample linking the electrical terminals to obtain thermodifferential analyses (DTA). These DTA thermocouples are fixed by internal screws to prevent possible displacement during the cycling goniometer rotations. To manage the Eurotherm thermal controller, the thyristor unit, the relay of the cooling fluid flow by a serial RS232 port, a marketable 
ITOOLS ver. 2.09 (Windows'98) program from Eurotherm, UK, was installed.

A homemade MS-DOS program package $(\mathrm{PLV}+$ SIRDAT) was used for full-duplex control of the x-ray diffractometer (Philips PW1710/00 with a PW1712 communication card) via a RS232 serial port. SIRDAT is a program that allows sequential data records to be processed. SIRDAT produces ASCII diffractograms in POW format to be used by RIETVELD or SIRPOW programs. PLV+SIRDAT are freeware. A Spanish version for MS-DOS can be obtained from one of the authors. ${ }^{4}$ The lector program can be evaluated by executing ftp://150.214.62.175/user IP direction (password=user, PLV program).

The $\mathrm{x}$ irradiation from the $\mathrm{x}$-ray diffraction tube is used to stimulate a wider emission spectrum (from 190 to 850 $\mathrm{nm}$ ). The resultant spectra (radioluminescence) are collected with a fiberoptic spectrometer. This complementary selfcoupling also allows control of the phase transition by spectral methods. An Ocean Optics S2000 collects spectra radioluminescence emissions from the sample (this is a 2048element linear CCD-array miniature fiberoptic spectrometer coupled to a Pentium III $800 \mathrm{MHz}$ PC). The stimulation source of the sample was a glass diffraction $\mathrm{x}$-ray tube (Philips $\mathrm{Cu}$ PW2253/20 operating at $30 \mathrm{kV}$ and $40 \mathrm{~mA}$ ). This classic broad focus $\mathrm{x}$-ray tube focuses onto a large impact area of $\mathrm{x}$ irradiation on the sample (approx $12 \mathrm{~mm} \times 6 \mathrm{~mm}$ ). A piece of stainless steel was turned to fit the fiber optic in the X-ray chamber [Figs. 1(A) and 2]. To control the spectrometer and to collect the spectra files by a serial RS232 port, a marketable Spectra-Win ver. 4.2 (Windows'98) program from The Netherlands was installed.

Two new thermocouples were added, one in the sample, and the other in a reference powder to obtain the thermal differences between the sample and the reference. Additional screw holes were drilled to fix both new thermocouples $\left(\mathrm{T}_{1}\right.$ and $\mathrm{T}_{2}$ ), connected in opposite modes. The resulting electrical signal, which is the difference between the welding of both thermocouples, is plugged into an analog to digital converter (ADC) 22 bit circuit (Analog Devices AD7710) controlled by a microcontroller ( $\mu$ C) (PIC16F84 from Microchip Technology Inc.). This controller changes the data from the ADC controller to the serial PC standard. An auxiliary circuit (Maxim MAX232) modifies the output levels to the complementary metal-oxide-semiconductor (CMOS)/RS232 standard. The circuit is fed by a $12 \mathrm{~V}$ stabilized source. The system collects 50 temperature measurements per second, which are then stored on $1 \mathrm{~h}$ (380 kbytes) binary files. The self-designed software (TAMBOR) allows ASCII data to be extracted.

Applications of the present device to crystallographic problems are widespread because $\mathrm{x}$-ray diffraction is a powerful tool when applied to solid-state kinetics. ${ }^{5,6}$ This lowcost, useful modification of a traditional diffractometer is practical for analyses of hydrated phases. The prototype was tested in order to observe dehydration of gypsum (gypsumbassanite-anhydrite) from alteration beds of urban marbles $\left(\mathrm{SO}_{2}+\mathrm{H}_{2} \mathrm{O}+\mathrm{CaCO}_{3} \rightarrow \mathrm{CaSO}_{4} 2 \mathrm{H}_{2} \mathrm{O}\right)$.

The authors are grateful to Paul Giblin for critical review of the manuscript, to Emilio Soteras for new mechanics (the door, etc.), and to Juan Jose de Paños for the software on spectra curves. The Spanish DGICYT PB98-0501 and European PNICYDT 1FD97-0959-C03-01 projects supported the work.

\footnotetext{
${ }^{1}$ J. Garcia-Guinea, R. Abella, S. Sanchez-Moral, R. Benito, and D. MartinRamos, J. Sediment. Res. 70, 964 (2000).

${ }^{2}$ I. C. Noyan, S. K. Kaldor, P. C. Wang, and J. Jordan-Sweet, Rev. Sci. Instrum. 70, 1300 (1999).

${ }^{3}$ M. W. Tate, S. M. Gruner, and E. F. Eikenberry, Rev. Sci. Instrum. 68, 47 (1997).

${ }^{4}$ The Spanish version for MS-DOS may be obtained from J. D. MartinRamos via e-mail: jdmartin@ugr.es.

${ }^{5}$ S. B. Sinott, J. Am. Chem. Soc. 119, 9588 (1997).

${ }^{6}$ M. Oetzel, F. D. Scherberich, and G. Heger, Powder Diffr. 15, 30 (2000).

${ }^{7}$ H. K. Camenga and M. Epple, Angew. Chem. 107, 1284 (1995).
} 